\title{
EVALUATION OF WATER QUALITY OF SOME WELLS AND ITS CORRELATION WITH SOME SOIL PROPERTIES IN SINAI
}

Rahmou, A. A. ${ }^{1}$; A. S. El-Henawy ${ }^{2}$ and M. A. B. El-Sherief ${ }^{1}$

${ }^{1}$ Soil, Water and Environment Res. Inst., Agric. Res. Center, Giza, Egypt

${ }^{2}$ Soil Dept., Fac. of Agric., Kafrelsheikh Univ., Egypt.

\begin{abstract}
The limited natural resource of water in Sinia is one of the major problems in agriculture sector. To study and evaluate the different water quality of some wells in North Sinia, a field investigation was performed by chosing 20 sites of soils which irrigated from besidly wells for a long time at El-Arish, Rafah and Sheikh Zuwayid. Water and surface soil samples were taken and analyzed. Simple linear regression relationships were conducted between some properties of wells water and soils.

The important results could be summarized as follows:

Irrigation water of wells at all locations have very and severe hazards of salinity and sodicity and they lie in categories between $\left(\mathrm{C}_{3}-\mathrm{S}_{1}\right)$ and $\left(\mathrm{C}_{4}-\mathrm{S}_{4}\right)$. Water content of soluble $\mathrm{Fe}, \mathrm{Mn}, \mathrm{Cd}$ and $\mathrm{Pb}$ are higher than the safty limits in all locations. Soluble $\mathrm{NH}_{4}{ }^{+}, \mathrm{NO}_{3}{ }^{-}$and $\mathrm{NO}_{2}^{-}$in water wells are less than the critical concentration of safe using.

Soils which were sandy and loamy sandy were found non-saline in most locations as affected by irrigation water quality. Soil content of available $\mathrm{Fe}, \mathrm{Mn}, \mathrm{B}$, $\mathrm{Pb}, \mathrm{Cd}, \mathrm{NH}_{4}{ }^{+}, \mathrm{NO}_{3}{ }^{-}$and $\mathrm{NO}_{2}^{-}$were low in all locations except $\mathrm{NH}_{4}{ }^{+}$and $\mathrm{NO}_{3}{ }^{-}$in soil around well No. 16.

A high negative correlation was found between, soil-pH and both of available $\mathrm{Fe}$ and $\mathrm{Mn}$ in soil $\left(-0.634^{* *} \&-0.732^{* *}\right)$ and between $\mathrm{CaCO}_{3}$ and available soil boron $\left(-0.489^{\star}\right)$. Also, a high significant postive correlation between water-pH and available soil boron was found $\left(0.656^{\star}\right)$.

Finally, wells water can be used for irrigation purposes in the area of study under control and with good a management(optimum tillage, adding organic matter and amendements and good croping system etc..).
\end{abstract}

\section{INTRODUCTION}

There is about 1.2 million feddan available to agriculture in North Sinia Governorate, which cultivated only about 192000 feddans from it. There are 3837 wells which include 54 deepest wells from that, (http://www.kananaonline.com). The limited natural resources of water in Sinia is one of the major problems in agriculture sector.

For crops irrigated infrequently, as is normal when use surface methods and conventional irrigation management, crop yield is best correlated with the average root zone salinity, but for crops irrigated daily, or near daily basis (localized or drip irrigation) crop yields are better correlated with the water-uptake weighted root zone salinity (Rhoades, 1982). According to various survey in India and Africa, $20-50 \%$ of wells contain nitrate levels greater than $50 \mathrm{mg} / \mathrm{L}$ and in some cases as high as several hundred milligrams per litre (Convey and Pretty, 1988). In the developing countries, it is usually wells in villages or close to towns that contain the highest levels, 
Rahmou, A. A. et al.

suggesting that domestic excreta are the main source, though livestock wastes are particularly important in semi-arid areas where drinking troughs are close to wells.

Several physical, chemical and biological soil managements help facilitate the use of saline water in crop production. Physical methods include cultural practices that can be expected to improve or maintain infiltration rates and permeabilty in the surface and root zone during the period of irrigation or rainfall (FAO 1992). Kandel et al. (2003) found that high significant correlation between the chemical composition of irrigation water used and soil chemical properties (whole profile), which predict the soil contamination due to irrigation with low quality water.

The aim of this study is to evaluate the different water quality of wells at North Sinia, Egypt and the correlation between some soil properties and water wells properties.

\section{MATERIALS AND METHODS}

To study and evaluate the different water quality of wells in North Sinia which used as sources of irrigation water for irrigation purposes, a field investigation was performed in June 2007 by chosing 20 sites of soils which irrigated from besidly wells for a long time at El-Arish, Rafah and Sheikh Zuwayid, as shown in Table (1) and Fig. (1).

Fig. (1): locations of study area. 
Distrubed soil samples were taken from the surface layer $(0-30 \mathrm{~cm})$ from soil which irrigated from arouned wells. Irrigation water samples were taken from wells and chemically analyzed (EC, $\mathrm{pH}$, and soluble ions), according to Klute (1986). Also, SAR, $\mathrm{Ca}^{+2} / \mathrm{Mg}^{+2}$, SSP, and $\mathrm{Na}^{+} / \mathrm{Ca}^{+2}$ parameters were calculated using Richard's equation (1954). Soluble $\mathrm{Fe}$, $\mathrm{Mn}, \mathrm{Pb}$ and $\mathrm{Cd}$ were determined using Perkin Elmer atomic absorption spectrophotometer model 2830. B was detemined by curcumin method according to Dible et al. (1954). Soluble $\mathrm{NH}_{4}^{+}, \mathrm{NO}_{3}^{-}$and $\mathrm{NO}_{2}^{-}$were determined by Kjeldahle method acccording to Cottenie et al. (1982). ECe, $\mathrm{pH}$ and soluble ions in soil paste extract were determined according to Klute (1986). Particles soil distrrubution was determined by pipette method according to Gee and Bauder (1986). $\mathrm{CaCO}_{3}$ was determined using Collin's calcimeter, and organic matter content as decribed by Walkely and Black according to Klute (1986). Available B in soil was extracted by hot water according to Wear (1965). Available $\mathrm{N}$ formes $\left(\mathrm{NH}_{4}{ }^{-}, \mathrm{NO}_{3}{ }^{-}\right.$and $\left.\mathrm{NO}_{2}^{-}\right)$were extracted by using $\mathrm{K}_{2} \mathrm{SO}_{4}$ according to Klute (1986). Available soil Fe, Mn, $\mathrm{Pb}$ and $\mathrm{Cd}$ were extracted by DTPA-method according to Cottenie et al. (1982). Correlation coefficient and simple regression between some water propeties and soils were done after Snedecor and Corchran (1972).

Table (1): Locations of soil samples taken around the wells in Sinia.

\begin{tabular}{|c|c|c|c|c|}
\hline $\begin{array}{l}\text { Well } \\
\text { No. }\end{array}$ & $\begin{array}{l}\text { Well Depth, } \\
\text { m }\end{array}$ & $\begin{array}{c}\text { Representive area, } \\
\text { Fed. }\end{array}$ & \multicolumn{2}{|l|}{ locations } \\
\hline 1 & 60 & 22 & \multirow{2}{*}{ Hode El-Mazraa } & \multirow{5}{*}{ El-Arish } \\
\hline 2 & 50 & 52 & & \\
\hline 3 & 56 & 30 & \multirow{3}{*}{ El-Amel Village } & \\
\hline 4 & 50 & 25 & & \\
\hline 5 & 50 & 28 & & \\
\hline 6 & 50 & 30 & Agricultural Research Farm & \multirow{7}{*}{ Raphah } \\
\hline 7 & 60 & 25 & \multirow{2}{*}{ Abo Sinar } & \\
\hline 8 & 60 & 17 & & \\
\hline 9 & 50 & 30 & \multirow{4}{*}{ Balha } & \\
\hline 10 & 50 & 32 & & \\
\hline 11 & 55 & 27 & & \\
\hline 12 & 50 & 50 & & \\
\hline 13 & 71 & 15 & Kasr El-Sherif & \multirow{5}{*}{ Sheikh Zuwayid } \\
\hline 14 & 16 & 22 & \multirow{2}{*}{ El-Sarasra } & \\
\hline 15 & 27 & 16 & & \\
\hline 16 & 45 & 20 & Hy El-Zohoar & \\
\hline 17 & 17 & 20 & Hy El-Margda & \\
\hline 18 & 50 & 21 & Lehn Bear & \multirow{3}{*}{ El-Arish } \\
\hline 19 & 50 & 40 & El-Mazara & \\
\hline 20 & 50 & 27 & Hode Mazara & \\
\hline
\end{tabular}

\section{RESULTS AND DISCUSSION}

\section{Evaluation of different water quality of wells at North Sinia:}

Mean values of chemical analysis of different water wells at different locations are presented in Table (2). Data showed that, EC values of wells water were high salinity level according to Ayers and Westcot classification (1985), where, EC values in wells No. 14, 15 and 17 were 1.97, 1.75 and 
$1.44 \mathrm{dS} / \mathrm{m}$, respectively. Also, These water lies in class $\left(\mathrm{C}_{3}-\mathrm{S}_{1}\right)$ according to Richards (1954), that means it can be used for irrigation pourposes in course soils and resistance type of plant growth to salinity hazard. EC value in well No. 8 is considered high salinity and lie in catogery $\left(C_{3}-S_{3}\right)$, that means it cause salinity and sodicity hazards when it use in irrigation. EC values in wells No. $13,18,19$, and 20 were severe salinity and lies in catogery $\left(\mathrm{C}_{4}\right.$ $\mathrm{S}_{2}$ ) that means cause high salinity problems and moderate sodicity hazard. EC values in wells No. 2, 4 and 16 are considered severe salinity and lies in catogery $\left(C_{4}-S_{3}\right)$, that means its salinity and sodicity hazards is severe. EC values in wells No. $1,3,5,6,9,10,11$, and 12 are considerd very high salinity and sodicity and lies in catogery $\left(\mathrm{C}_{4}-\mathrm{S}_{4}\right)$ which means that it can be used only in agriculture with some special limitations of soil properties and plant types.

Table (2): Mean values of chemical analysis of the different irrigation water samples of the wells in Sinai.

\begin{tabular}{|c|c|c|c|c|c|c|c|c|c|c|c|c|c|c|c|}
\hline \multirow[t]{2}{*}{ No. } & \multirow[t]{2}{*}{ H } & \multirow{2}{*}{$\begin{array}{l}\mathrm{EC}, \\
\mathrm{dS} / \mathrm{m}\end{array}$} & \multicolumn{4}{|c|}{$\begin{array}{c}\text { Soluble cations, } \\
\text { meq/L }\end{array}$} & \multicolumn{4}{|c|}{ Soluble anions, meq/L } & \multirow[t]{2}{*}{ SAR } & \multirow{2}{*}{$\begin{array}{l}\mathrm{Ca}^{++} / \\
\mathrm{Mg}^{++}\end{array}$} & \multirow{2}{*}{$\begin{array}{l}\mathrm{Na}^{+} / \\
\mathrm{Ca}^{++}\end{array}$} & \multirow[t]{2}{*}{ SSP } & \multirow[t]{2}{*}{ Class } \\
\hline & & & $\mathbf{C a}^{++}$ & $\mathbf{M g}^{++}$ & $\mathrm{Na}^{+}$ & $\mathbf{K}^{+}$ & 5 & $\mathrm{HCO}_{3}$ & r & So & & & & & \\
\hline & 49 & 123 & 28.40 & 26.60 & 68.00 & 0.47 & & & & & & 7 & 39 & 507 & $\mathrm{C}_{4} \mathrm{~S}_{4}$ \\
\hline & & & & & & ta & & & & & & & & & \\
\hline & & & & & & & & & & & & & & & \\
\hline & 74 & & & & &. & & & & & & & & & \\
\hline & 48 & & & & & 49 & & & & & & & & & \\
\hline & 14 & 33 & 0 & 4.70 & & 0.12 & & & & & & & & 80.29 & ${ }_{4} S_{4}$ \\
\hline & & & 40 & 4.80 & & 12 & & & & & .55 & & & & \\
\hline & 24 & & 40 & 1.20 & & & & & & & & & & & ${ }_{3} \mathrm{~S}_{3}$ \\
\hline & & & & 4.40 & & & & & & & & & & & \\
\hline & 05 & & 10 & 4.10 & & 0.12 & & & & & f. & & & 86 & \\
\hline & 48 & & 80 & 4.50 & 6. & 0.2 & & & & & 0 & & & 84 & ${ }_{4} \mathrm{~S}_{4}$ \\
\hline & 14 & 44 & .00 & 20 & & 0.25 & & & & & 12 & & & 1.9 & ${ }_{4} \mathrm{~S}$ \\
\hline 3 & 07 & 47 & 50 & 7.00 & 0.74 & 0.49 & & & & & 4. & & 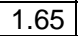 & 43.43 & ${ }_{4} \mathrm{~S}_{2}$ \\
\hline 4 & 8.10 & 97 & 00 & 5.20 & \begin{tabular}{|l|l|}
9.07 \\
\end{tabular} & 0.49 & & & & 16 & \begin{tabular}{|l|}
3.96 \\
\end{tabular} & & 81 & 45.90 & ${ }_{3} \mathrm{~S}_{1}$ \\
\hline 5 & 7.93 & 75 & 5.24 & 4.48 & 7.62 & 0.26 & & 0 & & & 3.46 & 7 & 5 & 43.30 & ${ }_{3} S_{1}$ \\
\hline & 22 & & 700 & 10.00 & & 0.30 & & & & & 10.36 & & & 8 & ${ }_{4} \mathrm{~S}_{3}$ \\
\hline & 8.20 & & 4.00 & 00 & 6. & 0.35 & & & & & .10 & & & & \\
\hline & 7.98 & & & 00 & & & & & & & 85 & & & & \\
\hline$y$ & 69 & 15 & 9.93 & 9.23 & & & & & & & 7.11 & & .26 & & \\
\hline 0 & 64 & 45 & & 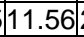 & $\mid<0$. & & $\pi$ & 4.18 & 28 & 12.6 & 0.04 & .05 & 1.71 & 40.40 & \\
\hline
\end{tabular}

From data obtained in Table (2), it was noticed that, generally, wells can be used for irrigation purposes in this area due to the course texture of soils which irrigated with these water for along time (Table, 4). This is agremeent with that introduced by Oster and Rhoades (1985).

Values of SAR and SSP of different wells are very high in wells No. (5, 9 and 11), moderate in wells No. $(1,2,3,4,6,7,8,10,11,12$ and 16), and low in other wells.

Data in Table (2) also show that, the dominate ions were $\mathrm{Na}^{+}, \mathrm{Cl}^{-}$and $\mathrm{SO}_{4}{ }^{-2}$ that are reflected on $\mathrm{Na}^{+} / \mathrm{Ca}^{+2}$ which were high excess twic in most wells except, wells No. $13,14,15,17,18$ and 20 . Values of $\mathrm{pH}$ indicated that water was found to be slightly alkaline. 
Mean values of some heavy metals and micronutrients of different water wells at different locations are presented in Table (3). Data show that, the mean concentration of soluble $\mathrm{Fe}$ and $\mathrm{Mn}$ are very highly concentration and higher than the safty limits ( 0.5 and $0.2 \mathrm{ppm}$ for $\mathrm{Fe}$ and $\mathrm{Mn}$, respectively) as recommended by Cottenie et al. (1982) and Alloway (1995). Pb and Cd concentrations in wells of water are higher than the safty limits in most wells except, in those were non-deticitve.

Table (3): Concentrations of some heavy metals and micronutrients in wells water samples in Sinia.

\begin{tabular}{|l|c|c|c|c|c|c|c|c|}
\hline \multirow{2}{*}{\begin{tabular}{l} 
Noll \\
\cline { 2 - 9 }
\end{tabular}} & $\mathbf{F e}$ & $\mathbf{M n}$ & $\mathbf{B}$ & $\mathbf{P b}$ & $\mathbf{C d}$ & $\mathbf{N H}_{4}{ }^{+}$ & $\mathbf{N O}_{3}{ }^{-}$ & $\mathbf{N O}_{2}{ }^{-}$ \\
\hline 1 & 18.57 & 7.63 & 0.36 & 3.67 & 0.210 & 2.27 & 0.71 & 0.108 \\
\hline 2 & 19.32 & 8.51 & 0.34 & 4.23 & 0.341 & 2.27 & 0.30 & 0.173 \\
\hline 3 & 18.50 & 30.14 & 0.41 & 4.51 & 0.273 & 2.01 & 0.02 & 0.864 \\
\hline 4 & 17.30 & 17.62 & 0.38 & 3.79 & 0.364 & 0.51 & 0.47 & $\mathrm{Nd}$ \\
\hline 5 & 16.43 & 13.02 & 0.39 & 3.96 & 0.316 & 5.04 & 0.14 & 0.216 \\
\hline 6 & 27.63 & 5.57 & 2.62 & 5.92 & 1.132 & 1.01 & 0.71 & $\mathrm{Nd}$ \\
\hline 7 & 5.95 & 26.51 & 2.14 & 2.91 & $\mathrm{Nd}$ & 0.76 & 0.25 & 0.216 \\
\hline 8 & 32.85 & 4.74 & 1.34 & 2.77 & 0.079 & 0.51 & 0.41 & 0.216 \\
\hline 9 & 17.54 & 24.57 & 0.25 & $\mathrm{Nd}$ & $\mathrm{Nd}$ & 0.76 & 0.57 & 0.216 \\
\hline 10 & 0.97 & 3.21 & 1.49 & 1.88 & $\mathrm{Nd}$ & 0.76 & 1.38 & 0.216 \\
\hline 11 & 25.23 & 5.54 & 2.52 & 5.49 & 1.122 & 0.76 & 0.57 & 0.216 \\
\hline 12 & 5.91 & 29.65 & 1.03 & $\mathrm{Nd}$ & $\mathrm{Nd}$ & 0.76 & 9.01 & 14.75 \\
\hline 13 & 8.73 & 44.96 & 0.32 & $\mathrm{Nd}$ & $\mathrm{Nd}$ & 0.25 & 3.94 & 0.216 \\
\hline 14 & 7.42 & 42.56 & 0.33 & $\mathrm{Nd}$ & 0.018 & 0.50 & 2.66 & 0.216 \\
\hline 15 & 6.31 & 22.42 & $\mathrm{Nd}$ & $\mathrm{Nd}$ & $\mathrm{Nd}$ & 0.76 & 0.14 & 0.324 \\
\hline 16 & 52.96 & 41.14 & 1.23 & $\mathrm{Nd}$ & 0.420 & 0.25 & 0.09 & 0.216 \\
\hline 17 & 13.79 & 5.33 & 0.11 & $\mathrm{Nd}$ & $\mathrm{Nd}$ & 0.51 & 1.73 & 0.216 \\
\hline 18 & 19.49 & 49.07 & 0.43 & 4.59 & 0.371 & 0.51 & 0.02 & 0.648 \\
\hline 19 & 15.62 & 35.07 & 0.28 & 3.67 & 0.285 & $\mathrm{Nd}$ & 0.15 & $\mathrm{Nd}$ \\
\hline 20 & 16.73 & 37.81 & 0.28 & 3.84 & 0.168 & $\mathrm{Nd}$ & 0.20 & 0.108 \\
\hline
\end{tabular}

$\mathrm{Nd}=$ non-detective.

Regarding to soluble B concentration wells No. 6, 7 and 11 has severe problems, where B was higher than $2.0 \mathrm{ppm}$. On other hand, wells No. 8, 10, 12 and 16 are cause moderate problems of $B$ when it use in irrigation due to the higher concentration of $B(\geq 0.75$ and $<2.0 \mathrm{ppm})$ while, concentration of soluble B didn't induce any problems when it use in irrigation at other wells which less than $0.75 \mathrm{ppm}$.

Regarding to nitrogen formes concentration in wells water $\left(\mathrm{NH}_{4}{ }^{+}, \mathrm{NO}_{3}\right.$ and $\mathrm{NO}_{2}{ }^{-}$) which refer to it were less than critical concentration according to Ayers and Westcot classification (1985).

Effect of wells water quality on some soil properties:

Mean values of chemical and physical properties of soil samples around the different wells are presented in Table (4). Data showed that, EC values of soil were less than $4 \mathrm{mmhos} / \mathrm{cm}$ in locations No. 3, 6, 7, 8, 9, 10, $11,13,15,16,17$ and 18. Also, EC values are located in saline soils catogeries according to soil diagnosis by Richards (1954) in locations No. 1, 2, 4, 14, 19 and 20. Soils are sodic-saline around the wells No. 5 and 12 . Soils are non-saline in most locations although water quality in these 
Rahmou, A. A. et al.

locations are very high salinity and sodicity hazards that due to the soils texture in these locations which the dominate percent of sand over than $80 \%$ and reduction in clay content. These results are in semi agreement with those obtained by Miller and Donahue, (1995), Buckman and Brady (1967) and Saskatchewan (1987). They showed that, soil texture plays an important role in all aspects of irrigation, and the role of soil texture with respect to the effect of salinity and sodicity is no exception. Texture is strongly correlated with a soils ability to percolate water (permeability and infiltration), how much water the soil can store (available water holding capacity), and the soil's ability to adsorb or desorb chemical ions (exchange capacity).

Table (4): Mean values of some soil chemical and physical parameters around the wells in Sinai.

\begin{tabular}{|c|c|c|c|c|c|c|c|c|c|c|c|c|c|}
\hline \multirow[t]{2}{*}{ No. } & \multirow[t]{2}{*}{ pH } & \multirow{2}{*}{$\begin{array}{l}\mathrm{EC}_{\mathrm{e}} \\
\mathrm{dS} / \mathrm{m}\end{array}$} & \multicolumn{3}{|c|}{$\begin{array}{c}\text { Soluble cations, } \\
\text { meq/L }\end{array}$} & \multirow{2}{*}{$\begin{array}{c}\text { ESP } \\
\%\end{array}$} & \multirow{2}{*}{$\begin{array}{l}\text { Soil * } \\
\text { Diagn- } \\
\text { osis }\end{array}$} & \multicolumn{3}{|c|}{$\begin{array}{c}\text { Particle Size } \\
\text { distribution, \% }\end{array}$} & \multirow[t]{2}{*}{ Texture* $^{\star}$} & \multirow{2}{*}{$\begin{array}{l}\text { Organic } \\
\text { matter \% }\end{array}$} & \multirow{2}{*}{$\begin{array}{c}\mathbf{C a C} \\
\mathrm{O}_{3} \\
\% \\
\end{array}$} \\
\hline & & & $\mathrm{Ca}^{++}$ & $\mathrm{Mg}^{++}$ & $\mathrm{Na}^{+}$ & & & Clay & Silt & Sand & & & \\
\hline 1 & 8.4 & 4.38 & 8.75 & 2.96 & 6.88 & 9.84 & $S$ & 12.90 & 3.02 & 84.08 & LS & 0.80 & 13.4 \\
\hline 2 & 8.6 & 6.00 & 11.88 & 3.45 & 11.88 & 11.25 & $S$ & 12.81 & 3.08 & 84.11 & LS & 0.59 & 8.1 \\
\hline 3 & 8.8 & 2.81 & 4.06 & 2.02 & 3.13 & 10.90 & NS & 3.93 & 3.84 & 92.23 & $\mathrm{Sa}$ & .61 & 3.8 \\
\hline 4 & 8.7 & 5.44 & 12.38 & 3.52 & 9.13 & 9.59 & $S$ & 3.96 & 3.85 & 92.19 & $\mathrm{Sa}$ & 0.42 & 4.6 \\
\hline 5 & 8.6 & 6.00 & 8.75 & 2.96 & 8.75 & 15.27 & SS & 3.92 & 3.86 & 92.22 & $\mathrm{Sa}$ & 0.49 & 8.1 \\
\hline 6 & 8.8 & 2.75 & 3.75 & 1.94 & 2.50 & 11.04 & NS & 3.96 & 3.88 & 92.16 & $\mathrm{Sa}$ & 0.15 & 3.8 \\
\hline 7 & 8.7 & 2.94 & 3.75 & 1.94 & 2.50 & 12.46 & NS & 3.74 & 3.54 & 92.72 & $\mathrm{Sa}$ & 0.38 & 4.6 \\
\hline 8 & 8.5 & 3.63 & 4.38 & 2.09 & 1.25 & 14.17 & NS & 7.68 & 4.00 & 88.32 & LS & 35 & 5.8 \\
\hline 9 & 8.8 & 2.56 & 3.75 & 1.94 & 2.50 & 10.18 & NS & 3.84 & 4.53 & 91.63 & $\mathrm{Sa}$ & 0.48 & 4.2 \\
\hline 10 & 8.7 & 3 & 3.75 & 1.94 & 2.50 & 13.47 & NS & 9 & 4.55 & 91.65 & $\mathrm{Sa}$ & 3 & 3.4 \\
\hline 11 & 8.6 & 3.94 & 5.63 & 2.37 & 3.75 & 12.97 & NS & 7.60 & 4.08 & 88.32 & LS & 0.52 & 3.2 \\
\hline 12 & 8.7 & 4.63 & 5.63 & 2.37 & 3.75 & 15.55 & SS & 7.68 & 4.01 & 88.31 & LS & 0.62 & 3.7 \\
\hline 13 & 8.2 & 1.31 & 3.75 & 1.94 & 1.25 & 2.53 & NS & 3.96 & 3.84 & 92.20 & $\mathrm{Sa}$ & 0.72 & 2.1 \\
\hline 14 & 7.7 & 4.06 & 7.50 & 2.74 & 3.75 & 10.31 & $S$ & 7.66 & 6.00 & 86.34 & LS & 0.69 & 4.3 \\
\hline 15 & 7.8 & 3.94 & 7.50 & 2.74 & 3.75 & 9.86 & NS & 3.91 & 3.80 & 92.29 & $\mathrm{Sa}$ & 0.75 & 4.1 \\
\hline 16 & 8.2 & 2.44 & 4.38 & 2.09 & 2.50 & 8.46 & NS & 3.93 & 3.84 & 92.23 & $\mathrm{Sa}$ & 0.80 & 2.1 \\
\hline 17 & 8.4 & 1.94 & 5.63 & 2.37 & 2.50 & 3.42 & NS & 4.07 & 3.82 & 92.11 & $\mathrm{Sa}$ & 0.83 & 2.5 \\
\hline 18 & 8.8 & 3.75 & 6.88 & 2.62 & 3.75 & 9.99 & NS & 7.65 & 7.00 & 85.35 & LS & 0.35 & 26.6 \\
\hline 19 & 8.7 & 6.25 & 15.31 & 3.91 & 7.50 & 9.12 & $S$ & 7.68 & 7.02 & 85.30 & LS & 0.55 & 26.5 \\
\hline 20 & 8.6 & 8.75 & 22.47 & 4.74 & 13.69 & 10.27 & $\mathrm{~S}$ & 7.61 & 7.07 & 85.32 & LS & 0.50 & 26.7 \\
\hline
\end{tabular}

* (S = Saline, NS = non-saline, SS = Sodic-saline, LS = Loamy sand, Sa = Sandy).

With regarding to soil organic matter, values are low in all locations. Also, values of total calcium carbonate are low except, in locations No. 18, 19 and 20 which excess than $20 \%$ that means it is calcarous soils.

Mean values of some available heavy metals and micronutrients in soils around the wells are presented in Table (5). Data show that, mean values of available heavy metals and micronutrients are low in all locations except, the values of $\mathrm{NH}_{4}{ }^{+}$and $\mathrm{NO}_{3}{ }^{-}$in location No. 16 which were 37.13 and $10.95 \mathrm{ppm}$, respectively. These trends were correlated with soil texture, organic matter and $\mathrm{CaCO}_{3}$. 
Table (5): Some heavy metals and micronutrients concentrations at (0 $30 \mathrm{~cm}$ ) soil samples around the wells in Sinai.

\begin{tabular}{|l|c|c|c|c|c|c|c|c|}
\hline \multirow{2}{*}{\begin{tabular}{l} 
Noll \\
\cline { 2 - 9 }
\end{tabular}} & $\mathbf{F e}$ & $\mathbf{M n}$ & $\mathbf{B}$ & $\mathbf{P b}$ & $\mathbf{C d}$ & $\mathbf{N H}_{4}{ }^{+}$ & $\mathbf{N O}_{3}{ }^{-}$ & $\mathbf{N O}_{2}{ }^{-}$ \\
\hline 1 & 3.84 & 3.02 & 0.51 & 1.37 & $\mathrm{Nd}$ & 3.78 & 2.07 & 1.19 \\
\hline 2 & 2.56 & 2.37 & 0.80 & 1.27 & $\mathrm{Nd}$ & 4.41 & 3.20 & 0.61 \\
\hline 3 & 4.72 & 2.74 & 0.71 & 1.48 & $\mathrm{Nd}$ & 6.92 & 4.44 & 1.09 \\
\hline 4 & 4.24 & 2.94 & 0.81 & 1.37 & $\mathrm{Nd}$ & 5.04 & 1.96 & 1.48 \\
\hline 5 & 3.79 & 3.02 & 0.71 & 1.27 & $\mathrm{Nd}$ & 5.66 & 2.27 & 0.61 \\
\hline 6 & 1.65 & 3.86 & 1.05 & 0.27 & 0.07 & 4.41 & 1.37 & 1.34 \\
\hline 7 & 2.70 & 2.73 & 1.14 & 1.15 & $\mathrm{Nd}$ & 4.41 & 4.02 & 2.38 \\
\hline 8 & 2.13 & 4.34 & 1.02 & 1.22 & $\mathrm{Nd}$ & 3.15 & 2.17 & 1.04 \\
\hline 9 & 4.85 & 3.15 & 1.15 & 1.29 & $\mathrm{Nd}$ & 4.41 & 0.21 & 0.04 \\
\hline 10 & 2.33 & 1.23 & 0.94 & 1.19 & $\mathrm{Nd}$ & 3.15 & 1.13 & 1.02 \\
\hline 11 & 3.59 & 2.18 & 1.05 & 1.24 & $\mathrm{Nd}$ & 4.41 & 2.48 & 0.68 \\
\hline 12 & 2.73 & 3.06 & 1.06 & 1.03 & $\mathrm{Nd}$ & 4.41 & 2.05 & 0.93 \\
\hline 13 & 6.09 & 5.01 & 0.94 & 1.21 & $\mathrm{Nd}$ & 3.15 & 0.93 & 0.11 \\
\hline 14 & 12.26 & 8.08 & 1.18 & 1.26 & $\mathrm{Nd}$ & 4.41 & 6.09 & 0.61 \\
\hline 15 & 6.81 & 7.89 & 1.01 & 1.21 & $\mathrm{Nd}$ & 3.05 & 1.34 & 1.02 \\
\hline 16 & 2.08 & 1.57 & 0.89 & 1.16 & $\mathrm{Nd}$ & 37.13 & 10.95 & 0.17 \\
\hline 17 & 3.05 & 3.18 & 0.71 & 1.37 & $\mathrm{Nd}$ & 4.41 & 1.09 & 0.82 \\
\hline 18 & 6.40 & 4.30 & 0.72 & 1.59 & $\mathrm{Nd}$ & 3.78 & 0.93 & 0.35 \\
\hline 19 & 2.56 & 2.37 & 0.80 & 1.27 & $\mathrm{Nd}$ & 5.11 & 0.17 & 1.06 \\
\hline 20 & 4.72 & 3.74 & 0.72 & 1.48 & $\mathrm{Nd}$ & 4.10 & 1.96 & 0.37 \\
\hline
\end{tabular}

Nd = non-detective.

The relation between some properties of wells water and soils:

Statistical correlation between water quality of wells and some soil properties are presented in Table (6). Data showed that, there were postive correlation between $\mathrm{EC}_{\text {iw }}$ and $\mathrm{EC}_{\mathrm{e}}, \mathrm{ESP}$ and soil-pH, but these relations were non significant. Also, there were non significant positive correlation between water-pH and both of available $\mathrm{Mn}, \mathrm{NH}_{4}{ }^{+}$and $\mathrm{NO}_{3}{ }^{-}$in soil, non significant negative correlation with available $\mathrm{Fe}$, and $\mathrm{NO}_{2}{ }^{-}$, and significant postive correlation at $1 \%$ level with available $B$ in soil $\left(0.656^{* *}\right)$, respectively.

The correlation between soil $\mathrm{pH}$ and available heavy metals and micronutrients are postive correlation except, with $\mathrm{NO}_{2}{ }^{-}$and non significant except, with $\mathrm{Fe}$ and $\mathrm{Mn}\left(-0.634^{\star \star} \&-0.732^{\star \star}\right)$. With regarding to correlation between soil organic matter and available heavy metals and micronutrients are non significant that may be due to the reduction in soil organic matter content in these soils and their arid conditions. Also, the correlation between soil $\mathrm{CaCO}_{3}$ and avialable heavy metals and micronutrients are non significant except, with available soil boron $\left(-0.489^{*}\right)$.

Finally, wells water can be used for irrigation purposes in the area of study under control and with a good management (optimum tillage, adding organic matter and amendements and a good cropping system etc..). 
Rahmou, A. A. et al.

Table (6): Statistical correlations between some properties of water and soil.

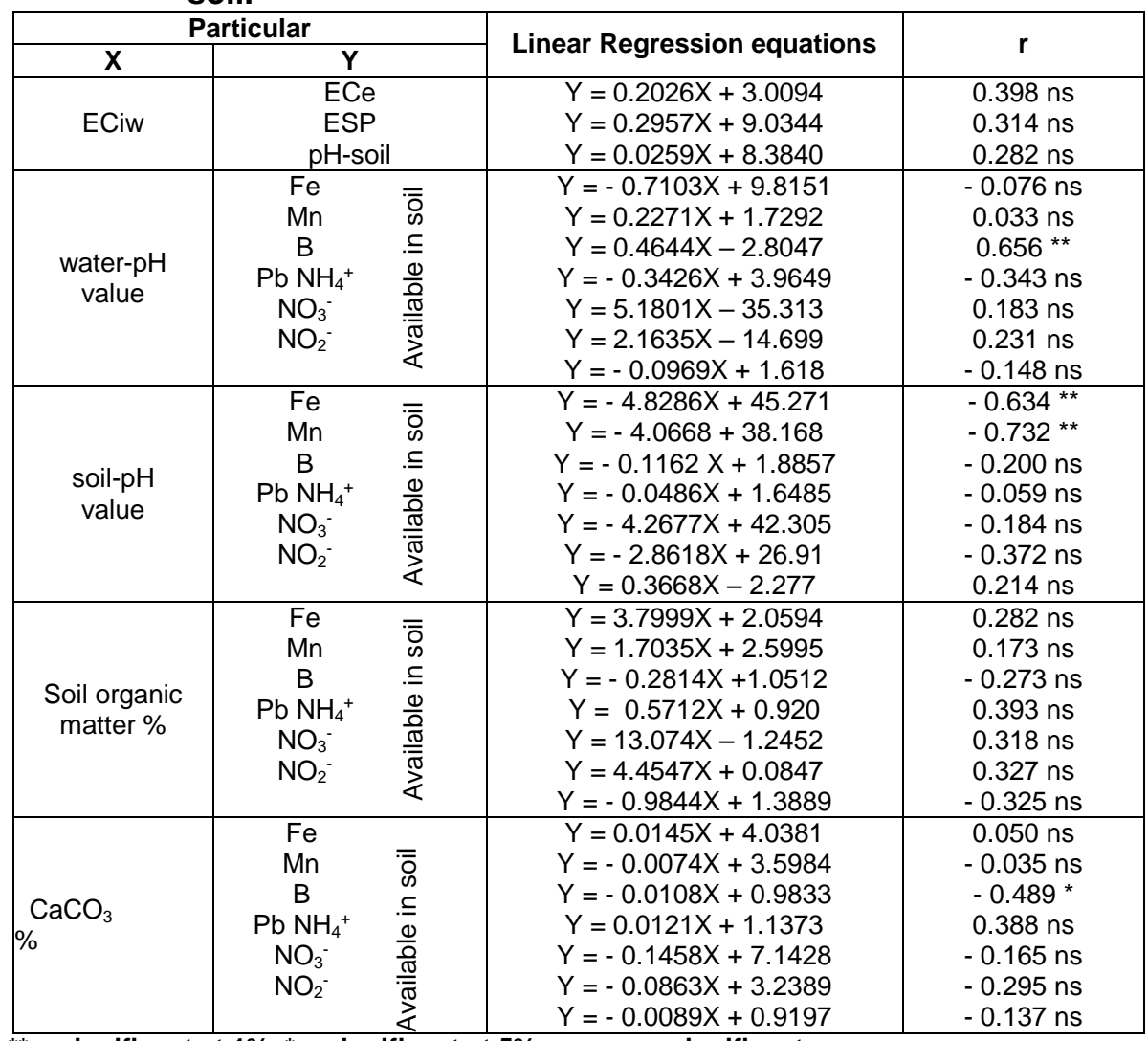

= significant at $1 \%,{ }^{*}=$ significant at $5 \%$, ns = non significant.

\section{REFERENCES}

Alloway, B. J. 1995. Heavy metals in soils. $2^{\text {nd }}$ Edition, Blackie Academic and Professional, UK.

Ayers, R. S. and D. W. Westcott 1985. "Water quality for agriculture". Irrigation and drainage paper, 29, Rev. 1. FAO, Rome, $174 \mathrm{pp}$.

Buckman, H.O. and N.C. Brady 1967. The nature and properties of soils. The MacMillan Company, New York, New York.

Convey, G.R. and J.N. Pretty 1988. Fertilizer risks in the developing countries: a review. International Institute for Environment and Development, London.

Cottenie, A.; M. Verloo; G. Velghe and L. Kiekens 1982. Biological and Analytical Aspects of Soil Pollution. Labo. of Analytical \& Agron. State Univ. Ghent-Belgium.

Dible, W. T., E. Tuog and K. C. Berger. 1954. Boron determination in soils and plants Simplified Curcumin procedure. Anal. Chem. 26, 418.

FAO (1992). The use of saline water for crop. FAO irrigation and drainage Paper 48., Rome. 
Gee, G. W. and J. W. Bauder 1986. Particle size analysis, in methods of soil analysis. C. f. Klute, A. (ed.) Part I. Agron. 9, 15: 383-409, Amer. Soc. Agron. Madison, Wisconsin, USA.

http://www.kananaonline.com/page/5663.

Kandil, N. F., F. M. Habib and W. A. Hafez, 2003. Statistical evaluation of soil and field crops pollution due to different irrigation water qualities. Egypt. J. Soil Sci. 43, No. 1, pp:77-90.

Klute, A. 1986. Methods of Soil Analysis (Part 1). Amer. Soc. of Agron, Inc. Madison, Wisconsin, USA. $3^{\text {rd }}$ edition.

Miller, R.W. and R.L. Donahue. 1995. Soils in Our Environment, Seventh Edition. Prudence Hall, Englewood, Cliffs, NJ. p. 323.

Oster, J. D. and J. D. Rhoades 1985. Water management for salinity and sodicity control. In: Stuart, G. and T. Asano. Irrigation with reclaimed municipal water. Lewis Publishers, INC. 7-1: 7-19.

Rhoades J.D. 1982. Reclamation and management of salt-affected soils after drainage. Proc. First Annual Western Provincial Conf. Rationalization of Water and Soil Resources and Management, Lethbridge, Alberta, Canada. 29 November-2 December 1982. pp. 123-197.

Richard, L. A. 1954. "Diagnosis and Improvement of Saline and Alkaline Soil". Agric. Handbook, No. 60, USDA.

Saskatchewan Water Corporation. 1987. "Irrigation Water Quality - Soil Compatibility: Guidelines for Irrigation in Saskatchewan." Saskatchewan Water Corporation, 60 pp.

Snedecor, G. W. and W. G. Corchran. 1972. Statistical methods, $6^{\text {th }}$ Ed. lowa State Univ., Amess. lowa.

Wear, J. I. 1965. Boron. in, Black, C. A. 1965. Methods of Soil Analysis, Part II. Amer. Soc. of Agron. Madison, Wisconsin, USA.

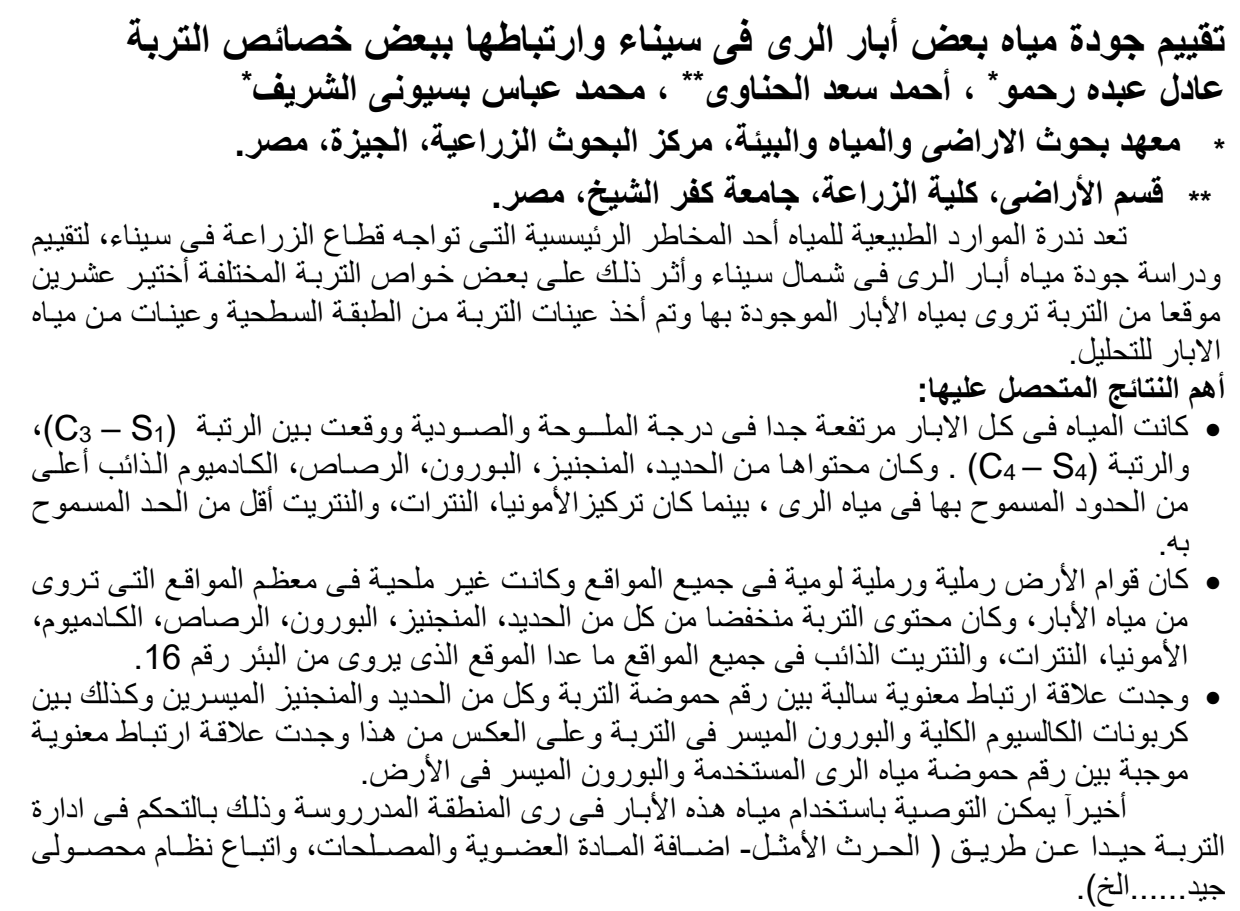

